\title{
Chapter 5 \\ The Role of Environmental Geohistory in High-Mountain Landscape Conservation
}

\author{
Albert Pèlachs, Ramon Pérez-Obiol, Joan Manuel Soriano, \\ Raquel Cunill, Marie-Claude Bal and Juan Carlos García-Codron
}

\begin{abstract}
Proper management of the perceived value of any geographic space requires the capacity to interpret research results from spatial, temporal, and environmental points of view, applying the principles of environmental geohistory. Basic concepts such as baseline, threshold, or resilience are discussed from a long-term ecological perspective, with examples that explain the dynamics of fir forests as well as the changes in agricultural cover. Studying the changes in the altitudinal limit of the forest and surveying the wetlands dynamics on the southern slopes of the central Catalan Pyrenees have been shown to be effective tools to develop appropriate management tasks. The arguments presented are useful to enrich the public debate over management policies for natural protected spaces in high-mountain areas.
\end{abstract}

Keywords Environmental geohistory - Conservation - Pyrenees - Abies alba • Human perturbation $\cdot$ Pedoanthracology $\cdot$ Palynology $\cdot$ Sedimentary charcoals

\footnotetext{
A. Pèlachs $(\square) \cdot$ J.M. Soriano $\cdot$ R. Cunill

Facultat de Filosofia i Lletres, Department of Geography, Edifici B,

Universitat Autònoma de Barcelona, 08193 Cerdanyola del Vallès,

Bellaterra, Spain

e-mail: albert.pelachs@uab.cat

R. Pérez-Obiol

Botany Unit, Facultat de Biociències, Department of Animal Biology,

Plant Biology, and Ecology, Edifici C, Universitat Autònoma de Barcelona,
}

08193 Cerdanyola del Vallès, Bellaterra, Spain

M.-C. Bal

Geolab UMR 6042 CNRS, Université de Limoges, 87000 Limoges, France

J.C. García-Codron

Department of Geography, Urban Studies and Land Planning,

Avenida de Los Castros s/n, Universidad de Cantabria, 39005 Santander, Spain

(C) The Author(s) 2017

J. Catalan et al. (eds.), High Mountain Conservation in a Changing World,

Advances in Global Change Research 62, DOI 10.1007/978-3-319-55982-7_5 


\subsection{Palaeoenvironment, Biodiversity and Protected Areas}

In recent decades, paleoenvironmental studies based on sedimentary records in mountain regions have contributed a large quantity of data that can help to explain the major environmental changes over time in different parts of the planet (Last and Smol 2001; Battarbe et al. 2005; Willis and Birks 2006; Catalan et al. 2013). The majority of these studies have focused on explaining the main vectors of global change, and have discussed the impact of human activities on planet Earth (Boada and Saurí 2002; Duarte 2006).

According to a recent international report, Protected Planet 2016, "there are 202,467 terrestrial and inland water protected areas recorded in the World Database on Protected Areas (WDPA), covering 14.7\% (19.8 million $\mathrm{km}^{2}$ ) of the world's extent of these ecosystems (excluding Antarctica)" (UNEP-WCMC and IUCN 2016: 30). The same source indicates that $19 \%$ of the world's mountain area has been declared Protected Areas, and in recent decades conservation policies have emphasized the role of protected areas in conserving biodiversity and cultural heritage. As Willis and Bhagwat (2010) point out, however, "since the first national park was established in 1872, [protected zones] are spatially fixed, meaning that migration beyond reserves in response to climate change may not be possible for many species" (Willis and Bhagwat 2010: 765). All of this occurs in a matrix that has been deeply affected by human impact and has experienced scenarios reflecting major climate changes in recent decades (IPCC 2014).

Taking all of this into account, Willis and Bhagwat ask, "how can we then create conditions that will protect native species beyond reserves and in novel ecosystems? This may require a whole new approach to conservation, restoring ecological processes and enhancing the quality of landscape matrix surrounding reserves" (Willis and Bhagwat 2010: 765). Is this reflection taking place? The answer is: at the theoretical level, yes — but only for the past decade - and at the practical level, no because of a lack of dialog between conservationists and the paleo-community (Sutherland et al. 2009). Some attribute this failure to communicate to a lack of awareness of scientific advances made by conservation managers, the absence of a long-term perspective that extends beyond 50 years, the priority given to the study of short time periods rather than the Holocene as a whole, and the self-imposed limitations within the scientific community when only the negative aspects of research attract attention (Froyd and Willis 2008). Other authors attribute the problem to differences between the palaeoecological descriptions used, without adjusting them to reflect the day-to-day management and conservation of biological diversity (Willis and Bhagwat 2010).

Richardson and Whittaker (2010) remind us that the conservation of biodiversity was formally defined during the past decade, when Whittaker et al. (2005) wrote about the biogeography of conservation and drew attention to four topics: (i) scale dependency; (ii) inadequacies in taxonomic and distributional data; (iii) developing improved understanding of the effects of model structure and parameterization, through increased sensitivity analyses; and (iv) areas in which applied theory 
derived from biogeographical science requires greater focused attention" (Whittaker et al. 2005: 318). That early 2000s, the expression 'ecosystem services' become formally stated as "the benefits people obtain from ecosystems" and highlighting "the consequences of the loss of biological diversity and degradation of ecosystem services for human well-being globally" (Sutherland et al. 2009: 560). Immediately thereafter, voices began to ask how to accomplish these things and what information was available to confront this challenge.

Willis and Birks (2006) pointed out the usefulness of studies based on sedimentary records in developing conservation policies. Their article, "What Is Natural? The Need for a Long-Term Perspective in Biodiversity Conservation," shows the value to environmental managers of taking a "longer temporal perspective to address specific conservation issues relating to biological invasions, wildfires, climate change, and determination of natural variability" and considered a temporal perspective "essential for meaningful modeling, prediction, and development of conservation strategies in our rapidly changing Earth." They conclude that the answer to the question "what is natural" lies in the historical analysis of environmental changes, and thereby can "start to provide important guidance for long-term management and conservation at local, regional, and global scales" (Willis and Birks 2006: 1261).

After developing 2,291 questions from a review of literature, Sutherland et al. (2009) selected 100 key questions for conservation practices: "The questions are divided into 12 sections: ecosystem functions and services, climate change, technological change, protected areas, ecosystem management and restoration, terrestrial ecosystems, marine ecosystems, freshwater ecosystems, species management, organizational systems and processes, societal context and change, and impacts of conservation interventions" (Sutherland et al. 2009: 558). The broad range of topics shows the complexity of the system, which was refined in each study included in their review. Richardson and Whittaker (2010) use six keywords that exemplify this complexity: "Biological invasions, climate change, conservation planning, data requirements, invasion ecology, and species distribution modeling" (Richardson and Whittaker 2010: 313). Their research shows the need for multi-proxy studies to explain the changes in biodiversity and contribute to its long-term conservation. Willis et al. (2010) conclude their article masterfully with this idea:

\footnotetext{
These archives indicate the complexity of responses to climate change over time, ranging from inherent variability through to rapid compositional turnover, broad-scale migrations, regime shifts, and the creation of novel ecosystems. They also indicate the dynamic interactions of biotic and abiotic processes that sometimes lead to thresholds and in other situations enable resilience and persistence. The record of these biotic responses obtained from paleoecological records provides a valuable resource for conservation strategies to conserve and manage ecological and evolutionary processes (Willis et al. 2010: 589).
}

In summary, biological conservation requires the analysis of a number of long-term states and processes in a world of extremely dynamic changes (Willis and Bhagwat 2010; Willis et al. 2010; Bradshaw et al. 2015) and a response to the following four questions: (1) What are the baseline or 'reference' conditions before recent times? (2) What is the range of natural variability? (3) Under what 
circumstances do negative impacts become apparent? (4) How can thresholds be determined beyond which specific management plans should be implemented? (Willis and Birks 2006: 1264). These questions lead us to various key concepts, as outlined below.

\subsubsection{Baseline and Range of Natural Variability}

A central aspect of any analysis is determining the 'baseline' or 'reference' conditions against which current changes can be assessed (Willis and Birks 2006; Froyd and Willis 2008; Willis and Bhagwat 2010; Willis et al. 2010; Bradshaw et al. 2015). Froyd and Willis (2008) agree with Lindbladh et al. (2007) that the "baseline is perceived as the ecosystem present before human influence became pronounced on the landscape" (Lindbladh et al. 2007). "Baselines are especially common in environmental regulation and ecosystem services" (Froyd and Willis 2008: 1724).

Closely related to this concept, Froyd and Willis (2008) also highlight the 'Range of Natural Variability' (RNV) of ecological systems; the central premise is that "resilient ecosystems will be maintained if land management activities operate within the range of conditions that would be expected under the natural disturbance regime" (Froyd and Willis 2008: 1725). This concept is promoted by managers with a vocation based on ecology, geography, etc. As these authors further explain, "application of the RNV incorporates the ideas of a historical baseline period or reference condition, but in addition the concept includes the implicit acknowledgement that ecological systems are not static and management applications should therefore vary, yet within a defined boundary range" (Froyd and Willis 2008: 1725). The question of how far back we should set the baseline is not exempt from dispute because it involves choosing a particular point on the space-time continuum, and this choice is not easy when we know that the landscape has never been static at any time in history. As Jackson and Hobbs (2009) point out, ecosystems are dynamic, fluid, and ever-changing, making it difficult to identify one moment in time to serve as a reference condition for the present situation.

\subsubsection{Thresholds and Ecological Resilience and Persistence}

In any case, it seems essential to set some thresholds, as Froyd and Willis (2008: 1726) indicated: "paleoecology holds great potential to inform conservation practice (...) through the identification of ecological thresholds, where the threshold is an abrupt change in an ecosystem and a switch from one stable state to another. The threshold concept is of particular interest to natural resource managers and policy makers because of the potential to define limits on the amount of 'acceptable' change an ecosystem can withstand." 
This perspective need not distract our attention from moments of 'stability' in the natural system because, even if thresholds of change are abrupt, successionwhether progressive or regressive, will be much longer (Margalef 1991). According to Dietl and Flessa (2011) there are three main ways in which species respond to changes in their environment: "(1) they can move, tracking environmental changes; (2) they can stay and adapt to the changing environment; and (3) they can fail to track habitats or to adapt, thus becoming extinct" (Dietl and Flessa 2011: 32). This leads us to reflect on a typology of time concepts (change, evolution, transformation, process) (Mendizábal 2013), without neglecting another key concept: resilience, a term that is currently used in many fields. Froyd and Willis (2008: 1726) defined resilience as "the ability of systems to absorb disturbance and still maintain the same relationships between populations (...). Thus resilience is the magnitude of disturbance that can be tolerated before a system moves to another stable state." At present, the study of resilience is being applied to the effects of climate change and paleoecological archives that help us understand why some ecosystems are more resilient to climate change than other and identify different degrees of resilience in different systems. The number of available studies and the contributions of genetic diversity have been another important factor for the maintenance of resilience in studies on the conservation of genetic diversity (Willis et al. 2010).

The general debate has focused on the study of interactions between climate, ecological processes, and human activities in the past in order to better understand the behavior of ecosystems in the present and future (Dearing and Battarbe 2007). In this context, high-mountain zones have been considered among the most sensitive and vulnerable to the environmental changes predicted for the 21 st century and one of the priority areas for attention to the value of natural attributes (Huber et al. 2005).

The reason for this is that human activity cannot be decoupled from landscape because they form part of it: "Over 75\% of the Earth's terrestrial biomes now show evidence of alteration as a result of human residence and land use" (Willis and Bhagwat 2009: 807). Most western European forests today "have long and diverse histories of anthropogenic disturbance and current conservation values incorporate both natural and cultural features" (Bradshaw et al. 2015: 194). In this sense, pollen studies with high spatial resolution have shown that simple temporal concepts like 'natural baselines' and the continuity of forest cover underestimate the complexity of the past (Bradshaw et al. 2015). What is the main problem? The complex nature of the relations between climate change and human activities. Why? For the following reasons:

(a) The same evidence/variable may indicate different things, and these may change over time.

(b) The same effect may have multiple possible origins that are completely opposite and therefore can have multiple origins that are completely opposite and therefore antagonistic. For example, Willis and Birks (2006: 1263) wrote that it "is not unreasonable to assume that an increase in aridity would result in more fires; several studies indicate otherwise." They base their argument on the 
cases of Alaska and the Northern Great Plains grasslands of North America to explain how greater humidity brings with it increased the risk of forest fires, showing how the levels of complexity are increasing. In the study of forest fires, there is a complicated climate-fuel-fire relationship that determines the variability of wildfires (Willis and Birks 2006).

If ecological systems are dynamic at natural scale (i.e., long-term ecological records $>50$ years), why is management often carried out within a static framework, dealing with short-term changes ( $<50$ years)? Various studies have shown that it not possible to manage the natural environment without considering the dynamics beyond that 50-year timeline (Willis and Birks 2006; Willis and Bhagwat 2010). In a synthesizing review in the Applied Ecology journal, Froyd and Willis (2008) affirmed that the majority of publications in the conservation/applied ecological literature still focus on very short timescales (i.e., years or decades). Willis and Bhagwat commented: "Paleoecological records are replete with examples of biotic responses to past climate change and human impact, but how can we use these records in the conservation of current and future biodiversity?" (Willis and Bhagwat 2010: 759). The solution involves always considering the long-term perspective and providing a test of "predictions and assumptions of ecological processes that are directly relevant to management strategies necessary to retain biological diversity in a changing climate" (Willis and Bhagwat 2010: 759).

\subsubsection{Why Environmental Geohistory and Not Only Environmental History?}

The term 'environmental history' has been in use for years, despite other labels that have received a certain media notoriety (Fontana 1992; Pèlachs 2006), although some sectors of ecology have begun to take it into account more recently (Whittaker et al. 2005). Therefore, we share the view of the temporal dynamic described by Dietl and Flessa (2011), who understand historical ecology in a broader sense, based on two perspectives: one limited to relatively recent time intervals (i.e., the Pleistocene) and another that concentrates on ecological dynamics (e.g., changes in species distribution and abundance). They conclude the following: "(1) the temporal scope of conservation paleobiology also extends to the pre-Pleistocene record; and (2) conservation paleobiology, in addition to ecological dynamics, concentrates on evolutionary dynamics (e.g., adaptive responses of species to changing climates or ecological interactions)" (Dietl and Flessa 2011: 31). Our concept of environmental geohistory also considers the spatial variable as a key factor. The temporal dynamic, combined with the spatial variable, constitutes geohistory: time (dynamics) is as important a variable as is space (scale). Froyd and Willis (2008) remind us that time and space are concepts that do not always go hand in hand with paleoecology. Environmental geohistory only exists if both variables are treated at the same time, but not if they are considered separately. As Dietl and Flessa (2011: 


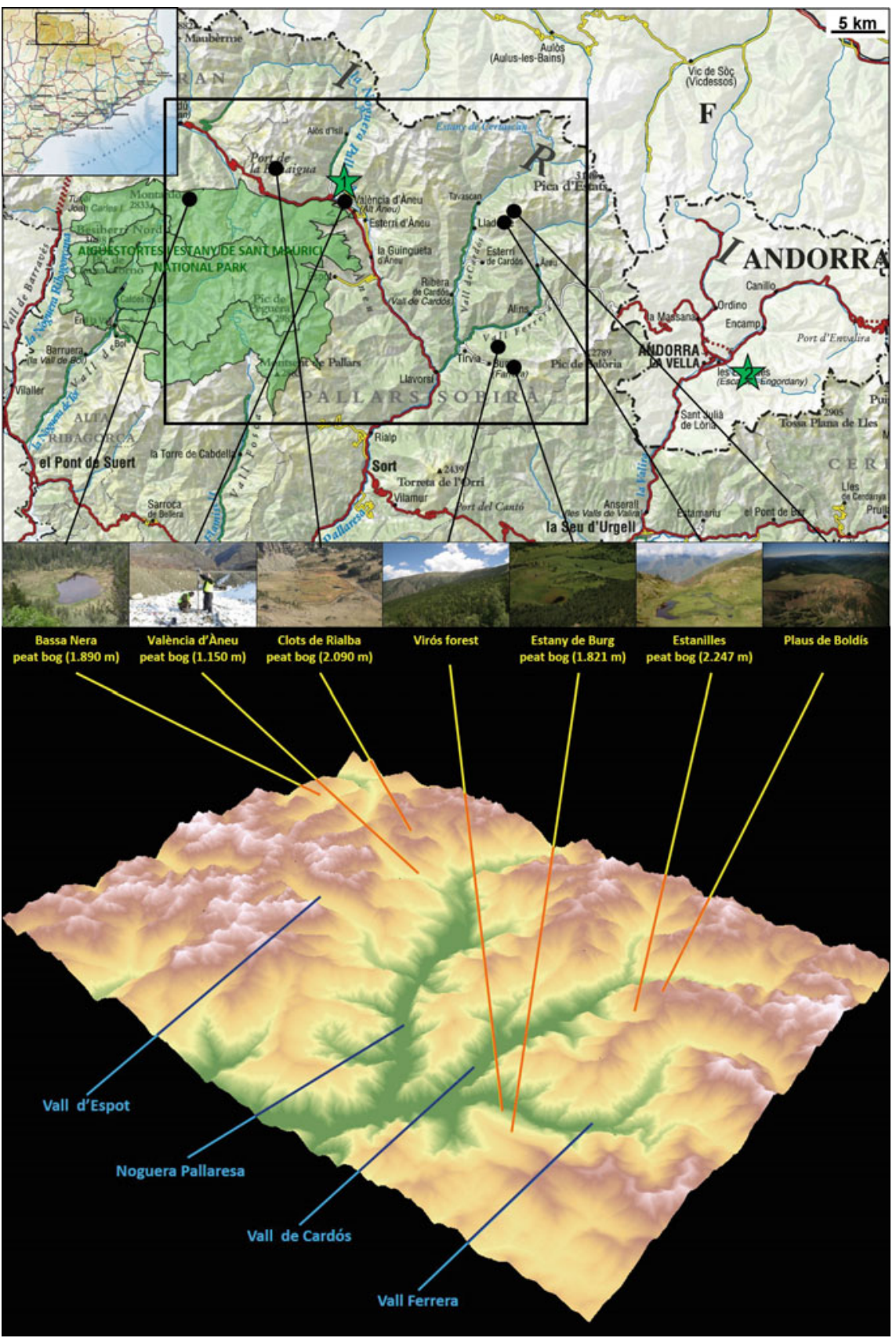

Fig. 5.1 Paleobotanical sites considered in this study [Sites with partial or definitive results are indicated with black dots. The two green stars (1 Solana de Sorpe; 2 Vall de Madriu, Andorra) indicate works in progress (no results to date)] 
30) put it, "our message is that the perspective provided by geohistorical data is essential for the development of successful conservation strategies in the midst of a constantly changing environment."

Environmental geohistory is an instrument with a focus on the future. Therefore, this chapter attempts to answer questions asked by managers by providing current examples that contribute information about diversity baselines, thresholds, resilience, and restoration of ecological processes (Willis and Bhagwat 2010). As Froyd and Willis (2008) point out, "the analysis of late Quaternary environmental change to key environmental issues of biodiversity and conservation management and examines areas which could be strengthened in the future including: (i) determination of baselines and natural ecosystem variability; (ii) understanding ecological thresholds and resilience; (iii) climate change conservation strategies; (iv) biological invasions; and (v) conservation and culture" (Froyd and Willis 2008: 1723). Willis et al. (2010) commented, "the message that emerges is that such paleo-records have much to offer not only regarding understanding the ecological and evolutionary processes responsible for biodiversity but also in guiding the management strategies necessary to ensure biodiversity conservation" (Willis et al. 2010: 584). Paleoecological records provide evidence of numerous climate changes and human impacts. The key to the question lies in how these records are used to benefit current and future conservation of biodiversity (Willis and Bhagwat 2010).

The main objective of this chapter is to contribute information and reflection on diversity baselines, thresholds, resilience, and restoration of ecological processes, based on three specific, structured examples in various settings with different levels of human intervention: (1) Abies and Betula as examples of forest changes permit a discussion of baseline and Range of Natural Variability at different stages of succession; (2) Alpine pastures at the tree line and agricultural mountain areas show the importance of thresholds and resilience in the management of more humanized spaces; (3) Peat bogs, the maximum expression of local environments, demonstrate that a lack of resilience requires maximum attention by managers. Both unpublished and previously published data will be presented to illustrate examples from the Pyrenees in areas surrounded by Natural Protected Spaces, both 'Aigüestortes i Estany de Sant Maurici National Park' and 'Alt Pirineu Natural Park' (Fig. 5.1).

\subsection{Examples of Environmental Geohistory in the Pyrenees}

\subsubsection{The Baseline and Range of Natural Variability of Abies Alba Mill}

In western Europe, Abies alba is distributed across the central and southern part of the continent; further north, Picea abies is the dominant genus. On the Iberian Peninsula, this species reaches its southwestern boundary in Europe, with its largest 
extension of forest area in the Pyrenees (approximately 50,000 ha); we find the southernmost populations in the Montseny massif (Costa et al. 1998). At present, the stands are highly fragmented and in some cases degraded by human activity (Alba-Sánchez et al. 2010). Their environmental needs include atmospheric humidity, dense cover for proper germination, and resistance to cold, placing this species below the altitude limits of Pinus uncinata, in other words at the subalpine and montane level. The species can also share the ecological range of Fagus sylvatica, with which it can form mixed stands of forest (Costa et al. 1998).

The available information about the paleogeographic history of Abies alba and its current distribution generates a long list of questions about its environmental history (genetic changes, a shift in distribution areas, etc.) and origins (colonization, refuge populations, etc.) in the Iberian peninsula. These questions must be answered to understand its current distribution, predict future developments within the current framework of global change, and support better management of the species.

Various paleogeographic studies at the European level, mainly in the Alps and Apennines, have shown the decrease in the distribution area of firs, compared to the mid-Holocene (ca. 5000-6000 years ago). At that time, the species would have achieved a dominant presence in the montane zones and low-altitude areas (Schneider and Tobolski 1985; Tinner et al. 1999; Wick and Möhl 2006). In the Pyrenees, environmental geohistory studies have confirmed this trend (Jalut 1988; Pèlachs et al. 2009b; Galop et al. 2013; Cunill et al. 2015). A study by Cunill et al. (2015) in fir populations at $300 \mathrm{~m}$ altitude on the north slope of the Pyrenees showed that, far from being anomalies or the fruits of repopulation efforts, these arboreal masses are witness to the greater importance of firs in the past in low pre-Pyrenees zones and a presence in the area for at least 5000 years.

It has not always been possible to apply the concepts of resilience, baseline, and RNV to managing these forests because we still lack knowledge of their paleoecological history and distribution. During the late glacial periods, Abies alba withdrew to refuge zones (still little-known to this day) and then at the beginning of the Holocene migrated progressively from east to west along the Pyrenees range. It appears earlier in the Mediterranean Pyrenees (in Estanilles about 8500 years cal BP, in the Burg Lake about 8000 years cal BP), and later in the Bassa Nera of the Atlantic-influenced Aran Valley (at about 6500 years cal BP) (Jalut et al. 1998; Esteban et al. 2003; Pèlachs et al. 2009b). In coming years, recently initiated pollen and genetic studies should begin to provide more information on this topic (Sancho-Knapik et al. 2014; Matías et al. 2016).

Palynological studies of five sedimentary records (Fig. 5.1) confirm the change over time in the presence of Abies alba and provide new data about the chronology of its dynamics (Pèlachs et al. 2009b; Bal et al. 2011; Pérez-Obiol et al. 2012; Cunill et al. 2013). In addition, other techniques of high spatial precision such as soil charcoal analysis or sedimentary macroremains analysis have confirmed this chronology and provided more information about the altitudinal and local distribution. Our group has found Abies alba on the shady and sunny sides of both slopes 
of the Pyrenees, at Montbrun-Bocage (Cunill et al. 2015) and Vall de Madriu et al. (work in progress).

At present, minimum Abies values have been found in all the diagrams studied. Human impact, as well as Holocene climatic changes leading to temporary moisture deficits, may have had a significant impact on the Abies forests. The species is considered to be less competitive on the sunny slope. Nevertheless, its rapid quantitative decline can only be understood if the silver fir was growing in habitats outside its current range. Millennia of land use could have eliminated Abies alba from the warmest portions of its potential range. Matías et al. (2016) recently suggested that the greater genetic diversity observed in the oldest populations of Abies alba provides greater resistance to drought and therefore the decline in silver fir could be a consequence of reduced genetic variation and the corresponding lack of adaptability.

The current presence of most firs is at the lowest level in history in the study area (Fig. 5.2). In an analysis of Holocene history between 4000 and 5000 years cal BP in Burg and Bassa Nera sequences and between 6000 and 7500 years cal BP in Estanilles peat bog, Abies alba would have had a much more important presence before the high human impacts observed. This time-point could provide the ecological baseline to be taken into account for conservation management studies. However, this abundance could be explained by their location on the sunny slope, as the values from Burg Lake, for example, seem to indicate. Beginning in 4200 years cal BP, the decline coincides with a period of rapid climate change (Bond Event 3) and with the beginning of the Bronze Age in the region (Pèlachs et al. 2011).

A period of recovery coincided with the influence of Roman period. After this phase, firs would never regain their previous coverage. In several pollen diagrams (Coma de Burg, Estanilles, and Bassa Nera), it seems that there was a selective management of firs or an unfavorable climate for these forests during this period. The Abies percentage curves behaved differently from the arboreal pollen curve (AP $\%$ ) (Fig. 5.2). Some of our data are in good agreement with data from the Alps and descriptions of the Romanche Valley, which explain the selective exploitation of firs in the Roman period (Nakagawa et al. 2000).

Was the recovery of firs in the Pyrenees after the human perturbations a consequence of management? The data show marked declines after the Late Roman period that could be related to intensive, generalized exploitation across the last two millennia. Therefore, the RNV should, in any case, precede this decline, although it is hard to pinpoint because of the many human and climatic changes occurring throughout the entire time period.

From a forest management perspective, the question is whether or not fir should be harvested at present. There are two conflicting positions: one argues that selective cutting will encourage regeneration and the other contends that the trees should not be touched. The first is based on the notion that, if we have arrived at the current situation of a certain forest quality, it is thanks to the forest management efforts of the past century. The data, however, demonstrate that this is not the case. The interventionist management of recent centuries is precisely the reason for the Abies alba decline. 

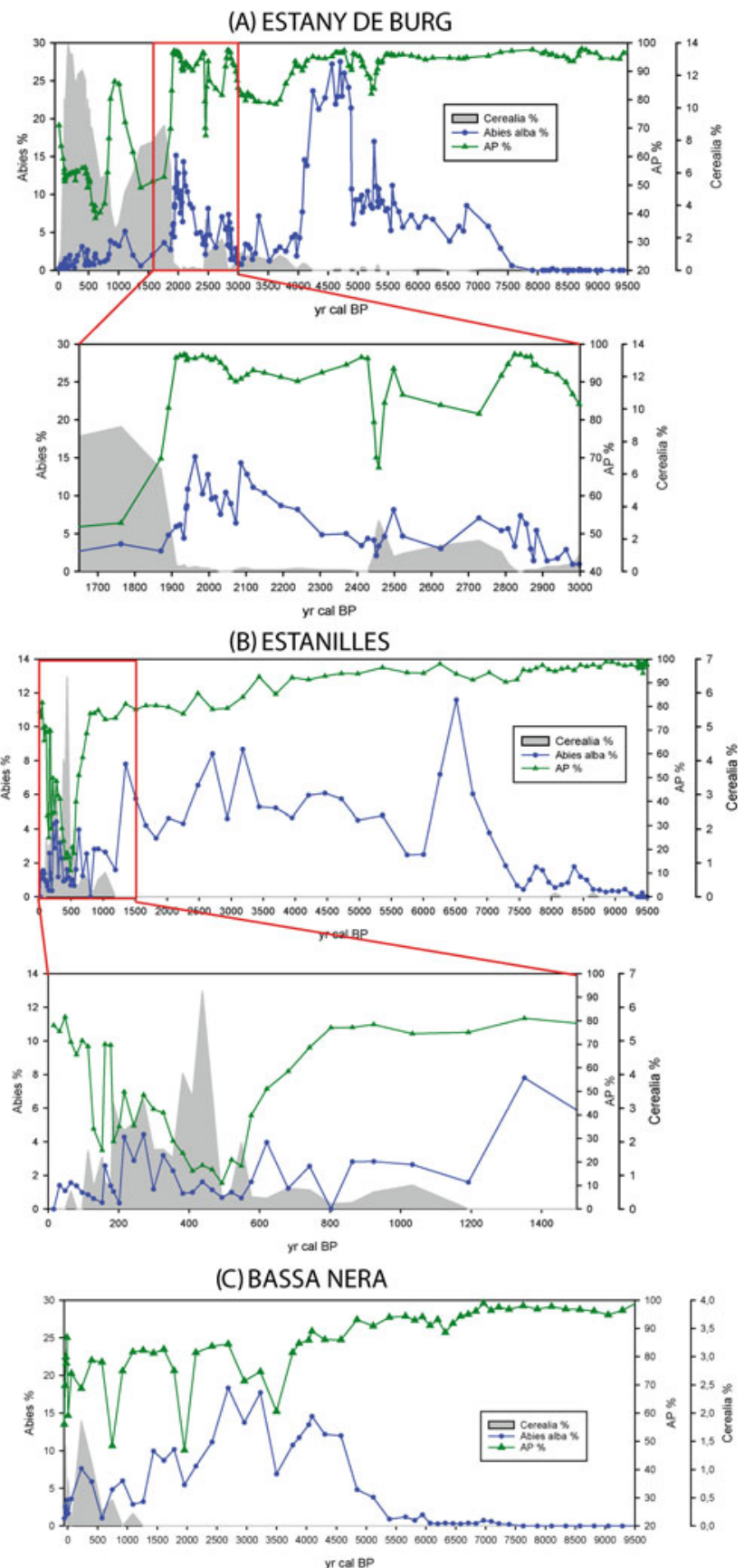

Fig. 5.2 Abies alba dynamics in some valleys of the Pyrenees [Estanilles results modified from Cunill et al. (2013) and Burg partially published in Pèlachs et al. (2011)] 
What can we learn from the historical dynamics of Abies alba? Is there some type of human management that had previously benefited or harmed the firs? In any case, human impact, more than climate, appears to be the primary factor in local extinction and the loss of genetic diversity and, consequently, the loss of adaptability (Carcaillet and Muller 2005).

\subsubsection{Are Baseline and Range of Natural Variability Appropriate Concepts for Secondary Communities?}

Although Costa et al. (1998) reported that Betula is widely distributed across the northern and medial zones of the European subcontinent, in the south its presence becomes progressively weaker. In the Iberian peninsula, these trees often dot other forest formations, such as Eurosiberian or sub-Mediterranean, although it is also possible to find them in more or less pure stands. Therefore, from the viewpoint of current forest management, knowing the origin of the small birch woods that are scattered across the panorama of other forests or whether there are stable birch forests is of great interest to conservation efforts.

In the Pyrenees, we find two species: Betula pendula and Betula pubescens. Being heliophilous plants, they have serial behaviors, meaning that in the process of succession that allows the original forest to recover, they act as pioneers in the successional sequence after disturbances in other forest masses or other sites that are difficult to colonize. Birch is a eurioic genus, capable of rapid natural expansion under favorable conditions, i.e., heavy production of light, winged seeds, vegetative regeneration, and easy germination (Costa et al. 1998). Therefore, the discussion concerns whether birch should be considered a secondary formation or the optimum forest vegetation, which would not be unusual in the presence of rexistasia and geomorphological activity (landslides, avalanches, etc.).

From a paleoecological perspective (Fig. 5.3a), birch propagated rapidly at the beginning of the Holocene, when the last glaciation had relegated to far distant areas the various forest patterns that today occupy the territory, allowing a broader distribution than in present times. Later, its distribution was limited to small populations in more favorable local habitats, which contributed to its persistence during the rapid climate changes that followed. At present, when thinking about ecological succession after a system has been strongly modified by human action, we tend to consider changes in forest structure at human scale. That is why birch stands have not traditionally been considered a stable 'final' status but rather an intermediate phase of a succession. What happens if these secondary dynamics extend more than 100 years? During the beginning of the Holocene, birch woods have been stable formations in the Pallars Sobirà region, and it was not until recent millennia that they have adapted to specific, greatly disturbed areas. Therefore, the same species of this genus may have had two totally differentiated preferences over the course of time, and a species considered to be mainly secondary in the Pyrenees today might 

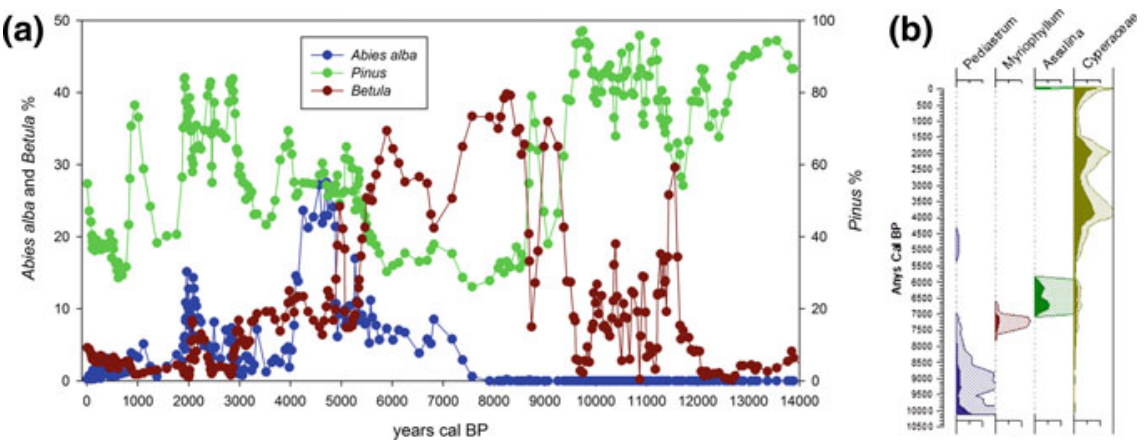

Fig. 5.3 a Holocene dynamic of the birch, the fir, and the pine at Burg Lake [partially published in Pèlachs et al. (2011)]. b Local environment in Bassa Nera during the Holocene [partially published in Pèlachs et al. 2016]

have had a different profile in the past (Fig. 5.3a). When these pioneer formations are being analyzed, the problem is greatest when attempting to define the ecological baseline and RNV. As indicated by Alagona et al. (2012: 65): "Restoration requires historical baseline targets, but all such targets are arbitrary for ecosystems that are constantly changing and have always been doing so (...) Recasting historical knowledge not as a narrow search for singular baseline conditions or specific population figures, but as a way to track multifaceted ecological changes over time, offers a middle ground where the past may inform but not determine the ecosystems of the future. The past may be imperfect as a model for the future, but it is an indispensable guide for understanding a world in flux."

At present, there is no special management of birch in the National Park. It is an opportunistic pioneer species that has adapted to colonizing unstable settings such as landslide channels and places with limited soil. Both species mentioned above, Betula pendula and B. pubescens, are found in this zone; the first is much more abundant now. We do not know whether this was also the case in the past, but it seems clear that $B$. pubescens must have a certain priority for conservation because it represents a relic of the past.

\subsubsection{How Should Open Spaces Cleared for Human Activities Be Managed When They Have a Semi-natural Function?}

The European Community's Directive 97/62/EC defines 198 habitats of community interest. In Catalonia, 94 habitats of community interest have been identified, of which 22 are prioritized. Among these habitats we find the acidic peat bogs of Sphagnum (see Sect. 2.5), natural and semi-natural grasslands (e.g., meadows 
of Nardus stricta, rich in flowers and sandy mountain soils of the mid-Atlantic or sub-Atlantic) and ecotonic bands of mountain with clusters of Cytisus oromediterraneus or Juniperus communis, among others, that colonize the meadows. In many cases, these areas are directly related to the open spaces and ecotonic areas that contain a great diversity of habitats.

At present, a topic of discussion is whether management must be based on a certain level of active human disturbance, or if open spaces can be maintained from a naturalist point of view. Fires and domestic cattle are indispensable elements for the first option, and there are wild plant-eating animals for the second. A second idea expressed by Willis and Bhagwat (2010: 765) is that "understanding the relationship between past herbivore densities and their role as 'ecosystem engineers' is an important future research challenge for long-term ecology." In both cases, the arboreal reforestation that could exist without either of these interventions is discarded. Just as we are told that not all meadows have an exclusively human origin, there are also natural origins, which quickly become the excuse to label the landscape as deteriorated and of little priority for conservation efforts, when it could mean exactly the opposite and have important endemic species of high conservation priority (Willis and Bhagwat 2010).

The altitudinal boundary of the forest is used to study climate change (Grau et al. 2013) and human impact (Catalan et al. 2013). As we have seen, however, the limits of the 'natural forested areas' have been substantially altered by the uses during recent centuries. That is why managing the forest for multiple uses, agricultural and livestock management and even improving animal habitat require knowledge of how the forest boundaries have varied to apply conservation policies.

A study by Cunill et al. (2013) carried out in the Vall de Cardós using pedoanthracology, palynology, and sedimentary charcoals deduced the transformation of the Pyrenean landscape, specifically the forest boundaries, during the Holocene (Fig. 5.4). Analysis of the data showed that human management has affected the forest boundaries. Fire, along with pastures and agriculture, has had a decisive role for thousands of years. Therefore, the current configuration of alpine and sub-alpine belts has been equally or more influenced by human action than by climate factors.

We could ask ourselves, why we value stability when studying vegetation succession but assign less value to systemic stability that results from human activity. Once again, the discussion must occur between two conflicting points of view: one side thinks that a certain dose of human disturbance contributes to the diversity of habitats and, therefore, to biodiversity; the others argue that the absence of human perturbations and the trend toward landscape homogenization that occurs with a high degree of maturity (e.g., in a mature forest) is the best way to encourage the natural system. The key question is, where is the limit? Does the management of protected natural spaces necessarily favor biodiversity by way of heterogeneity of habitats or will prolonged homogeneity lead to sufficient maturity and richness of species and biodiversity over time? 


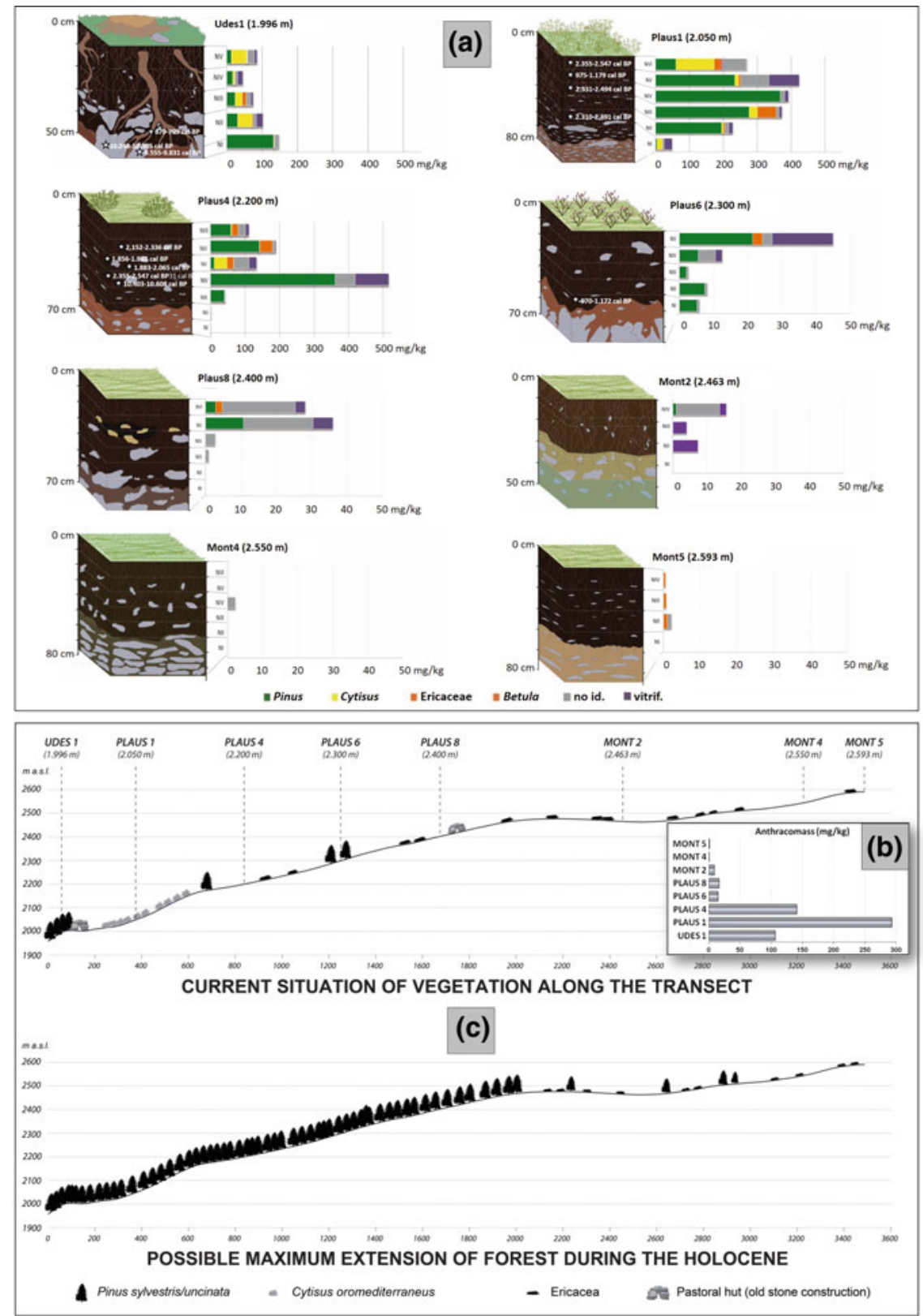

Fig. 5.4 a Anthracomass is defined as the quantity of charcoal per kilogram of dried soil and was calculated on the basis of the mass of charcoals larger than $0.8 \mathrm{~mm}$ (expressed in milligrams) and the total mass of the fraction of dry soil less than $5 \mathrm{~mm}$ (expressed in kilograms). The soil charcoal analysis showed that anthracomass was present at all sampling points. b Pedoanthracological diagrams (modified from Cunill et al. 2013). Taxon-specific anthracomass (TSA) by level in an elevational transect, expressed in $\mathrm{mg} / \mathrm{kg}$. $\mathbf{c}$ Theoretical profile of the upper forest boundary, based on the anthracomass at the time of maximum Holocene forestation, compared to the present 


\subsubsection{From the Late Roman to the Medieval Age Was Born the Open Landscape: Threshold Forestry Without Turning Back?}

If we analyze the intensity of human disturbance in our mountains, agriculture would be among the most important. As Willis and Bhagwat (2010) point out, based on examples from around the world, "Many of the landscapes in so-called biodiversity hotspots have a long history of human habitation and have been under some form of cultivation in the past" (Willis et al. 2004). The socioeconomic changes of the second half of the 20th Century led to the abandonment of many traditional practices related to the primary sector, and the Pyrenees are no exception (García-Ruíz et al. 1996). The loss of biodiversity associated with farming and livestock mosaics is a subject of debate in the management of Natural Spaces, to the extent that in recent years some of them, such as the Alt Pirineu Natural Park, have put in place policies of recovering fields and planting cereal crops. According to Willis and Bhagwat (2009: 807), "It has long been assumed that in a fragmented landscape, the fragment size and its isolation are important factors in determining species persistence; the smaller and more isolated the fragment, the lower its occupancy." One idea that contradicts the forest recolonization that provoked the abandonment of the traditional farming and livestock system in the valleys and mid-slopes. Bradshaw et al. (2015) summed it up this way: "Long forest continuity may be of importance for the local survival of higher plants, but for the insects, fungi, lichens, and bryophytes that are so valued in contemporary European temperate and boreal forests, habitat diversity maintained by dynamic processes would appear to be of greater significance" (Bradshaw et al. 2015: 194). This issue is also under discussion. Should managers strengthen the farming and livestock mosaic? Should agriculture be incentivized? Managers ask for specific answers, but policy management must be more general (Dietl and Flessa 2011). The following is an example of a threshold from more than a thousand years ago.

To understand the agricultural system, we analyzed the curves of cereals and grasses on the pollen diagram for Burg Lake, observing that the starting point of the modern farming and livestock system began about 4250 years cal BP (Fig. 5.5). The trend has clearly been on the increase, especially over the last two millennia. In other words, in the past 2000 years, there has never been such a small farming and livestock system in that study area. During those two millennia, the landscape has almost always been more open than it is now and forest recovery has clearly been in deficit compared to the recovery of pastures and open spaces.

A paradigmatic case occurred in Estanilles (Fig. 5.2), where deforestation was at its maximum 500 years ago, with AP\% below one-third, coinciding with a maximum curve of cereal pollen. The peculiarity of this case is that this process occurred at an altitude of 2247 m.a.s.l., which is usually associated only with pastures. Nonetheless, the data indicate an open farming and livestock landscape without trees.

Is the speed and intensity of these changes comparable throughout history? The current landscape often inhibits our ability to see beyond the human scale 


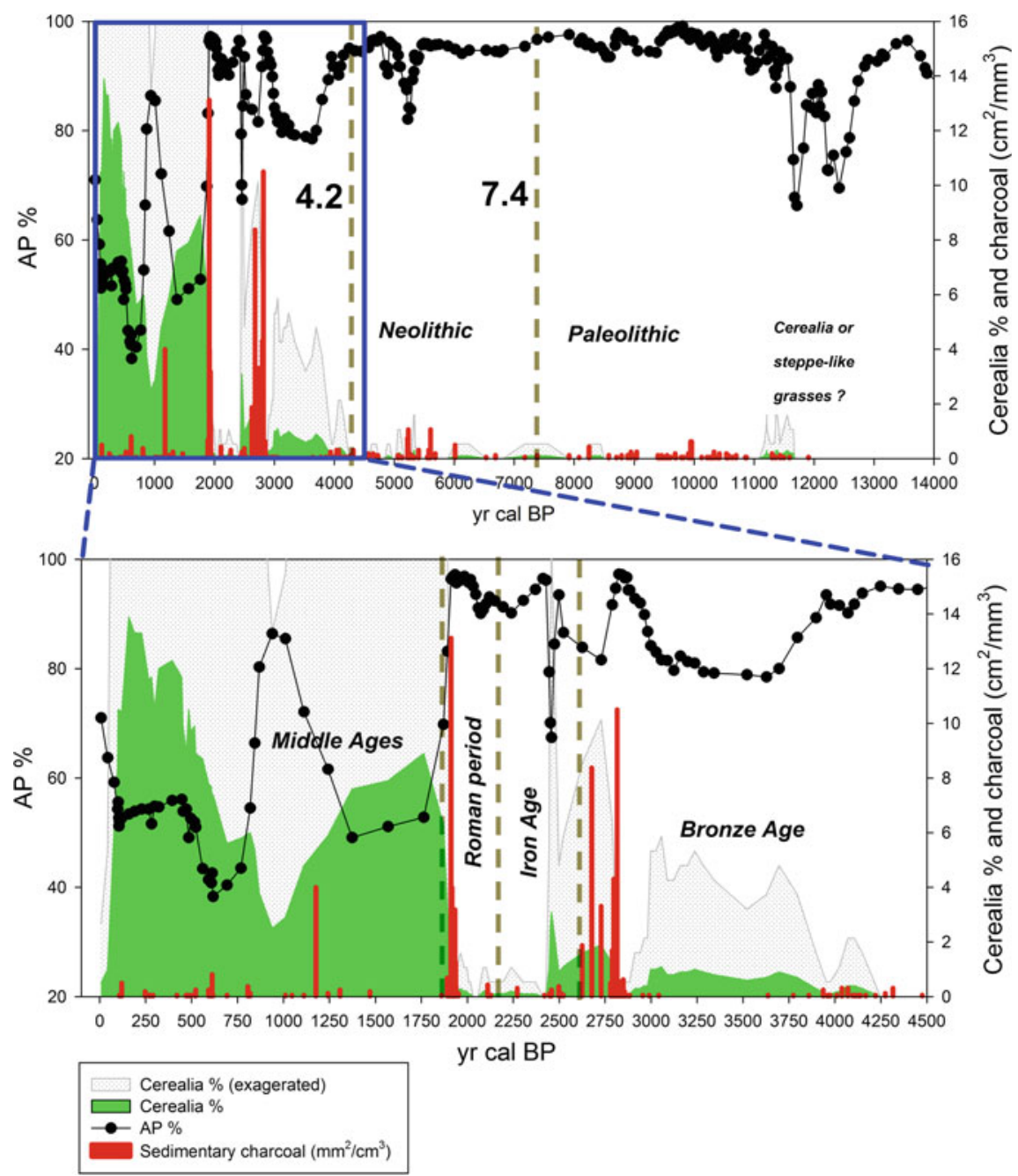

Fig. 5.5 The agricultural system at Coma de Burg [sedimentary charcoal partially published in Bal et al. (2011) and Gassiot et al. (2014)]

(decades or, in the best case, a few generations). There has been a highly accelerated and profound transformation as a result of human action during the 20th century, due to the exploitation of fossil fuels and technical and technological improvements. However, there also were notable changes in intensity level at the transition from the Roman period to the Late Roman or Late Middle Ages. From a forest point of view, the Pyrenees were more radically transformed during the first centuries of our era than what is now occurring - or at least the changes are comparable - and marked a threshold that represented the beginning of a deforestation of the space that will never again return to 'the way it was' (Fig. 5.5). In addition, we cannot uncouple the 
development of new agricultural spaces from the disappearance of forest species, such as the loss of beech from the Mata, València d'Àneu (Pèlachs et al. 2009b). Similarly, we cannot separate the use and management of fire as a means of creating clearings in the woods from other aspects of agricultural and livestock management over almost the past 3000 years (Bal et al. 2011).

It seems clear that management of natural spaces cannot dispense with an analysis of human influence at a very local scale. Also, the generalized fragmentation of habitats and the widespread creation of open spaces occurred 'only' during the past three millennia. The high temporal resolution seems to be one of the keys to studies of the dynamics of natural systems, but the high spatial resolution is the only way to test its effects. Among the examples from mountain areas in Spain, we would point out studies of the effects of agricultural abandonment around the Cadí (Soriano 1994; Molina 2000), the intensity of charcoal kilns and forest exploitation in the Viros forest of Vallferrera (Pèlachs et al. 2009a), or high-altitude vegetation dynamics in the Pyrenees (Cunill et al. 2013).

Nonetheless, this focus on details does not obscure the importance of each piece forming part of a larger picture; management also must be global because the key to good planning will always be found at medium scale and in the overall vision. At what scale, then, should we consider habitat diversity? As we have seen, geohistory does not encourage a generic response; on the contrary, accurate data are needed to be able to integrate different scenarios that combine various levels of intervention and fragmentation and guarantee biodiversity based on diverse formulas. Management of the natural surroundings in mountain areas can never be approached at the global level.

\subsubsection{Local Environments Appear to Have no Resilience!}

In analyzing local-level dynamics, we need to take into account the observation that "the search for the universal in the infinitesimally small" is a common theme in most cultures (Haskel 2014: 12). If we apply this concept to forest management and planning, the key question is the minimum surface area a species must occupy before it has 'value.' The maximum protection of nature in our study area occurs in the National Park. With the park, the most restrictive areas are the Integral reserves (Article 24, Natural Spaces Law 12/1985, 13 June), spaces preserved from any human intervention where only scientific research activities and the sharing of natural values. The National Parks at Aigüestortes and Estany de Sant Maurici are very localized spaces characterized by their exceptional values. Nevertheless, in a National Park, it is pertinent to ask if this is the proper management policy. Why are the integral reserves in a National Park small sites and not large protected areas?

For example, the integral reserves of peat bog, such as Bassa Nera or Trescuro in Aigüestortes i Estany de Sant Maurici National Park, contain a large part of the natural values recognized by the Natura 2000 network (Carreras and Farré 2014). Within the National Park they are small sites, highly localized, with very specific 
and unique characteristics. At Bassa Nera pond, as explained by Pérez-Haase (2016), 110 species of vegetation have been identified in 35 inventories, of which 11 are designated as rare species. Their singularity is based on their presence in ditches and borders, spaces where the humid ecosystem offers the most stressful conditions.

Environmental geohistory helps us to think about whether it has always been this way: How long ago was it a peat bog? What would be its dynamic? Does it make sense to preserve or protect it? The study of local vegetation demonstrates the extraordinary variability and mobility of the particular place. In this sense, the ombrotrophic raised bog at Bassa Nera has functioned for 60 years, alternating between emerging and submerging episodes for most of the Holocene with high environmental sensitivity (Fig. 5.3b). In other words, during the same period of time one of them could be an emerging peat bog but the other a submerging one. The point, in this sense, is to protect the Beta diversity. The substantial variability of these parts of the landscape, with a definite intra-annual seasonality (Catalan et al. 2013), convert the surrounding into places of extreme sensitivity, where resilience seems not to exist. Changes occur from one day to the next, and cannot be reversed. Therefore, the key is to adjudicate them in zones with maximum protection.

\subsection{Final Considerations}

Environmental geohistory is a useful tool for the understanding and management of natural systems in high-mountain areas. It contributes information at different scales but acquires its greatest usefulness at mid-scale and in explaining differences in various parts of the territory. High-mountain natural systems are sensitive to climate change, but also to the human management that clearly had begun by the Neolithic, became significant over the past three millennia, and were present everywhere starting in the Middle Ages.

The examples provided show the following:

(1) The relationship between environmental geohistory researchers and environmental managers is essential. Incorporation of a long-term perspective is necessary to making decisions for the future. The error is found in attempts to replicate the past because the choices made will always be arbitrarily based on a point in time and space that cannot be repeated. Therefore, the past may be an imperfect model for the future, but it is an essential consideration because it reveals the possibilities for biodiversity.

(2) Policies for the restoration of a natural environment that are based on concepts such as baseline, RNV, threshold, resilience, etc. are essential for theoretical reflection but should not be either the key factor nor the excuse for decision-making by managers. The modern key is found in the environmental values that are to be conserved, which requires that the natural dynamic of the 
system be incorporated (i.e., the protected boundaries must be neither fixed nor stable) and that human impact be acknowledged, along with the degree of human disturbance that is necessary to conserve biodiversity in a climate scenario that is never the same. All options for the future must pass through the filters of environmental diversity and overall protection of the territory.

The specialization processes that resulted from exploiting the natural resources of each valley have influenced the configuration of the current landscape and require that managers make localized and global decisions. Therefore, the environmental geohistory of firs in the Pyrenees has shown that the current distribution is the least extensive since initial colonization. Human management of the forest, as well as climate factors, might have favored their presence during the Roman period.

The data indicate that this is the first time in the last 2000 years that the farming and livestock landscape opened by humans is being abandoned, giving way to rapid recovery of arboreal cover, on a human timescale: 60 years. Criteria should be established to determine whether historical evidence has been appropriately considered in making a decision to maintain a cultural landscape or return it to its wild state.

The fragmentation of the landscape that has persisted over the past two millennia is leading to forest homogeneity. The role and characterization of secondary communities and potential natural vegetation should be considered at different time scales as part of future studies analyzing the phases of stability and the periods of profound changes.

Acknowledgements This chapter was made possible by two coordinated project grants from Spain's Ministry of Economics and Competitiveness (MEC), "El uso del fuego y la conformació de los paisajes en la Montaña cantábrica y el Pirineo oriental: estudio comparado de su evolución historica y tendencias actuales" (CSO2012-39680-C02-01), awarded to the Department of Geography, Urban Studies and Land Planning, Universidad de Cantabria and "Geohistoria ambiental del fuego en el Holoceno. Patrones culturales y gestión territorial desde el inicio de la ganadería y la agricultura en la montañana Cantábrica y Pirineo," awarded to the Department of Geography, Universitat Autònoma de Barcelona (CSO2012-39680-C02-02). In addition, the project was funded by the Catalan government's applied geography program, 'Grup de Geografia Aplicada' (AGAUR, Generalitat de Catalunya, 2014 SGR 1090). Raquel Cunill gratefully acknowledges the Government of the Principality of Andorra, for the research grant on Andorran Issues, APTA007-AND/2014.

The authors appreciate the English language review by Elaine M. Lilly, Ph.D.

\section{References}

Alagona PS, Sandlos J, Wiersma YF (2012) Past imperfect: using historical ecology and baseline data for conservation and restoration projects in North America. Environ Philos 9(1):49-70

Alba-Sánchez F, López-Sáez JA, Benito-de Pando B, Linares JC, Nieto-Lugilde D, LópezMerino L (2010) Past and present potential distribution of the Iberian Abies species: a phytogeographic approach using fossil pollen data and species distribution models. Divers Distrib 16:214-228 
Bal MC, Pèlachs A, Pérez-Obiol R, Cunill R (2011) Fire history and human activities during the last 3300 cal yr BP in Spain's Central Pyrenees: the case of the Estany de Burg. Palaeogeogr Palaeocl 300:179-190

Battarbe RW, Gasse F, Stickley C (eds) (2005) Past climate variability through Europe and Africa, vol 6. Springer, Dordrecht

Boada M, Saurí D (2002) El canvi global. Rubes, Barcelona

Bradshaw RHW, Jones CS, Edwards SJ, Hannon GE (2015) Forest continuity and conservation value in Western Europe. Holocene 25:194-202

Carcaillet C, Muller S (2005) Holocene tree-limit and distribution of Abies alba in the inner French Alps: anthropogenic or climatic changes? Boreas 34:468-476

Carreras C, Ferré A (eds) (2014) Cartografia dels hábitats de Catalunya versió 2. Manual d'interpretació, Barcelona, El Tinter

Catalan J, Pla-Rabés S, Wolfe AP, Smol JP, Rühland KM, Anderson NJ, Kopácek J, Stuchlík E, Schmidt R, Koinig KA, Ll Camarero, Flower RJ, Heiri O, Kamenik C, Korhola A, Leavitt PR, Psenner R, Renberg I (2013) Global change revealed by palaeolimnological records from remote lakes: a review. J Paleolimnol 49:513-535

Costa M, Morla C, Sainz H (eds) (1998) Los bosques ibéricos. Una interpretación geobotánica, Barcelona, Planeta

Cunill R, Soriano JM, Bal MC, Pèlachs A, Rodríguez JM, Pérez-Obiol R (2013) Holocene high-altitude vegetation dynamics in the Pyrenees: a pedoanthracology contribution to an interdisciplinary approach. Quat Int 289:60-70

Cunill R, Métailié JP, Galop D, Poublanc S, Munnik N (2015) Palaeoecological study of Pyrenean lowland fir forests: exploring mid-late Holocene history of Abies alba in Montbrun (Ariège, France). Quat Int 366:37-50

Dearing J, Battarbee R (2007) Past human-climate-ecosystem interactions (PHAROS). PAGES News 15(1):8-10

Dietl GP, Flessa KW (2011) Conservation paleobiology: putting the dead to work. Trends Ecol Evol 26:30-37

Duarte CM (2006) Cambio Global: Impacto de la actividad humana sobre el sistema Tierra. Consejo Superio de Investigaciones Científicas, Madrid

Esteban A (Coord), Oliver J, Còts P, Pèlachs A, Mendizàbal E, Soriano JM, Nasarre E, Matamala N (2003) La humanización de las altas cuencas de la Garona y las Nogueras (4500 aC-1955 dC). Servicio Nacional de Parques Nacionales, Madrid

Fontana J (1992) La història després de la fi de la història. Reflexions i elements per a una guia dels corrents actuals. Vic, Institut Universitari d'Història Jaume Vicens Vives i Eumo editorial

Froyd CA, Willis KJ (2008) Emerging issues in biodiversity and conservation management: the need for a palaeoecological perspective. Quat Sci Rev 27:1723-1732

Galop D, Rius D, Cugny C, Mazier F (2013) A history of long-term human-environment interactions in the French Pyrenees inferred from the pollen data. Continuity and change in cultural adaptation to mountain environments. Springer, New York, pp 19-30

García-Ruiz JM, Lasanta T, Ruiz-Flano P, Ortigosa L, White S, González C, Martí C (1996) Land-use changes and sustainable development in mountain areas: a case study in the Spanish Pyrenees. Landscape Ecol 11:267-277

Gassiot E, Rodríguez D, Pèlachs A, Pérez-Obiol R, Julià R, Bal MC, Mazzucco N (2014) La alta montaña durante la Prehistoria: 10 años de investigación en el Pirineo catalán occidental. Trabajos de Prehistoria 71(2):261-281

Grau O, Ninot JM, Cornelissen JC, Callaghan TV (2013) Similar tree seedling responses to shrubs and to simulated environmental changes at Pyrenean and subarctic treelines. Plant Ecol Divers 6(3-4):329-342

Haskel DG (2014) En un metro de bosque: Un año observando la naturaleza. Turner, Madrid

Huber UM, Bugmann HKM, Reasoner MA (2005) Global change and mountain regions. An overview of current knowledge. Springer, Dordrecht

IPCC (2014) Climate change 2014: mitigation of climate change. In: Edenhofer O, Pichs-Madruga R, Sokona Y, Farahani E, Kadner S, Seyboth K, Adler A, Baum I, Brunner S, Eickemeier P, 
Kriemann B, Savolainen J, Schlömer S, von Stechow C, Zwickel T, Minx JC (eds) Contribution of working group III to the fifth assessment report of the intergovernmental panel on climate change. Cambridge University Press, Cambridge, United Kingdom and New York, NY, USA

Jackson ST, Richard JH (2009) Restoration in the light of ecological history. Science 325:567-568

Jalut G (1988) Les principales etapes de l'histoire de la forêt pyrénénne française depuis 15,000 ans. Monografías del Instituto Pirenaico de Ecología 4:609-615

Jalut G, Galop D, Belet JM, Aubert S, Esteban A, Bouchette A, Dedoubat JJ, Fontugne M (1998) Histoire des forêts du versant nord des Pyrénées au cours des 30000 dernières années. J Bot Soc Bot Fr 5:73-84

Last WM, Smol P (eds) (2001) Tracking environmental change using lake sediments, Volume 1: Basin analysis, coring, and chronological techniques, vol 1. Kluwer Academic Publishers, New York, Boston, Dordrecht, London, Moscow

Lindbladh M, Brunet J, Hannon G, Niklasson M, Eliasson P, Eriksson G, Ekstrand A (2007) Forest history as a basis for ecosystem restorationda multidisciplinary case study in a south Swedish temperate landscape. Restor Ecol 15:284-295

Margalef R (1991) Teoría de los sistemas ecológicos. Barcelona, Univ, de Barcelona

Matías L, Gonzalez-Díaz P, Quero JL, Camarero JJ, Lloret F, Jump AS (2016) Role of geographical provenance in the response of silver fir seedlings to experimental warming and drought. Tree Physiol 00:1-11

Mendizábal E (2013) ¿Hay alguna geografía humana que no sea geografía histórica? Revista de Geografía Norte Grande 54:31-49

Molina D (2000) Conservació i degradació de sòls a les àrees de muntanya en procés d'abandonament. La fertilitat del sòl al Parc Natural del Cadí-Moixeró. Bellaterra, Departement de Geografia, Universitat Autònoma de Barcelona

Nakagawa T, Edouard JL, de Beaulieu JL (2000) A scanning electron microscopy (SEM) study of sediments from Lake Cristol, southern French Alps, with special reference to the identification of Pinus cembra and other Alpine Pinus species based on SEM pollen morphology. Rev Palaeobot Palyno 108(1-2):1-15

Pèlachs A (2006) Algunes reflexions sobre geografia, paisatge i geohistòria ambiental. Documents d'Anàlisi Geogràfica 48:179-192

Pèlachs A, Nadal J, Soriano JM, Molina D, Cunill R (2009a) Changes in Pyrenean woodlands as a result of the intensity of human exploitation: 2,000 years of metallurgy in Vallferrera, northeast Iberian Peninsula. Veg Hist Archaeobot 18(5):403-416

Pèlachs A, Pérez-Obiol R, Ninyerola M, Nadal J (2009b) Landscape dynamics of Abies and Fagus in the southern Pyrenees during the last 2200 years as a result of anthropogenic impacts. Rev Palaeobot Palyno 156(3-4):337-349

Pèlachs A, Julià R, Pérez-Obiol R, Soriano JM, Bal MC, Cunill R, Catalan J (2011) Potential influence of bond events on mid-holocene climate and vegetation in southern Pyrenees as assessed from Burg lake LOI and pollen records. The Holocene 21(1):95-104

Pèlachs A, Pérez-Obiol R, Soriano JM, Pérez-Haase A (2016) Dinàmica de la vegetació, contaminació ambiental i incendis durant els últims 10.000 anys a la Bassa Nera (Val d'Aran). In: La investigació al Parc Nacional d'Aigüestortes i Estany de Sant Maurici. X Jornades sobre Recerca al Parc Nacional d'Aigüestortes i Estany de Sant Maurici. [Boí]: Parc Nacional d'Aigüestortes i Estany de Sant Maurici; Barcelona: Generalitat de Catalunya. Departament de Territori i Sostenibilitat, 2016, pp 75-87

Pérez-Haase A (2016) Patrons estructurals, ecològics i biogeogràfics en vegetació de molleres i de torberes d'esfagnes. Barcelona, Facultat Biologia de la Universitat de Barcelona. Unpublished doctoral dissertation

Pérez-Obiol R, Bal MC, Pèlachs A, Cunill R, Soriano JM (2012) Vegetation dynamics and anthropogenically forced changes in the Estanilles peat bog (southern Pyrenees) during the last seven millennia. Veg Hist Archaeobot 21(4-5):385-396

Richardson DM, Whittaker RJ (2010) Conservation biogeography-foundations, concepts and challenges. Divers Distrib 16:313-320 
Sancho-Knapik D, Peguero-Pina1 JJ, Cremer E, Camarero JJ, Fernández-Cancio Á, Ibarra N, Konnert M, Gil-Pelegrín E (2014) Genetic and environmental characterization of Abies alba Mill. Populations at its western rear edge. Pirineos 169 Enero-Diciembre, e007

Schneider R, Tobolski K (1985) Lago di Ganna-Late-glacial and Holocene environments of a lake in the Southern Alps. Diss Bot 87:229-271

Soriano JM (1994) Efectes del despoblament sobre el medi físic d'un territori de muntanya (Tuixén, Parc Natural Cadí-Moixeró). Estudi de la variació de la fertilitat del sòl en camps de conreu abandonats. Bellaterra, Departament de Geografia, Universitat Autònoma de Barcelona

Sutherland WJ, Adams WM, Aronson RB, Aveling R, Blackburn TM, Broad S, Ceballos G, Cote IM, Cowling RM, Da Fonseca GA, Dinerstein E, Ferraro PJ, Fleishman E, Gascon C, Hunter M Jr, Hutton J, Kareiva P, Kuria A, Macdonald DW, Mackinnon K, Madgwick FJ, Mascia MB, McNeely J, Milner-Gulland EJ, Moon S, Morley CG, Nelson S, Osborn D, Pai M, Parsons EC, Peck LS, Possingham H, Prior SV, Pullin AS, Rands MR, Ranganathan J, Redford KH, Rodriguez JP, Seymour F, Sobel J, Sodhi NS, Stott A, Vance-Borland K, Watkinson AR (2009) One hundred questions of importance to the conservation of global biological diversity. Conserv Biol 23:557-567

Tinner W, Hubschmid P, Wehrli M, Ammann B, Conedera M (1999) Long-term forest fire ecology and dynamics in Southern Switzerland. J Ecol 87(2):273-289

UNEP-WCMC and IUCN (2016) Protected planet report 2016 UNEP-WCMC and IUCN, Cambridge UK and Gland, Switzerland

Whittaker RJ, Araújo MB, Jepson P, Ladle RJ, Watson JEM, Willis KJ (2005) Conservation biogeography: assessment and prospect. Divers Distrib 11:3-23

Wick L, Möhl A (2006) The mid-Holocene extinction of silver fir (Abies alba) in the Southern Alps: a consequence of forest fires? Palaeobotanical records and forest simulations. Veg Hist Archaeobot 15:435-444

Willis KJ, Birks HJB (2006) What is natural? The need for a long-term perspective in biodiversity conservation. Science 314:1261-1265

Willis KJ, Bhagwat SA (2009) Biodiversity and climate change. Science 326:806-807

Willis KJ, Bhagwat SA (2010) Questions of importance to the conservation of biological diversity: answers from the past. Clim Past 6:759-769

Willis KJ, Gillson L, Brncic TM (2004) How "virgin" is virgin rainforest? Science 304:402-403

Willis KJ, Bailey RM, Bhagwat SA, Birks HJB (2010) Biodiversity baselines, thresholds and resilience: testing predictions and assumptions using palaeoecological data. Trends Ecol Evol 25:583-591

Open Access This chapter is licensed under the terms of the Creative Commons Attribution 4.0 International License (http://creativecommons.org/licenses/by/4.0/), which permits use, sharing, adaptation, distribution and reproduction in any medium or format, as long as you give appropriate credit to the original author(s) and the source, provide a link to the Creative Commons license and indicate if changes were made.

The images or other third party material in this chapter are included in the chapter's Creative Commons license, unless indicated otherwise in a credit line to the material. If material is not included in the chapter's Creative Commons license and your intended use is not permitted by statutory regulation or exceeds the permitted use, you will need to obtain permission directly from the copyright holder.

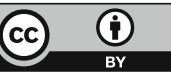

